\title{
Customer's Intention with Moderating Role of Pricing on Islamic Personal Financing of Pakistan
}

\author{
Sadia Saeed \\ Lecturer, National university of Modern Languages, Islamabad, Pakistan \\ sadiasaeed441@yahoo.com \\ Dr. Hina Shahab \\ Assistant Professor, National university of Modern Languages, Islamabad, Pakistan \\ hina.shahab@gmail.com \\ Dr. Shehla Akhtar \\ Assistant Professor, National university of Modern Languages, Islamabad, Pakistan \\ shakhtar@numl.edu.pk
}

\begin{abstract}
Financial industries are rapidly accepting the Islamic banking system. Using theory of reasoned action (TRA) model the study investigates the three factors including attitude, religiosity and subjective norms in measuring the intention of customers to adopt Islamic banking products along with moderating role of pricing. The sample of 220 banks consumers from two cities of Rawalpindi and Islamabad are gathered using convenient sampling. Regression results suggest that all three factors influence the intention of customers in buying Islamic banking products. Moreover, pricing moderates the relationship in developing intention of customer to adopt Islamic personal financing in the context of religiosity. The finding of the study identifies that Islamic bankers should adopt pricing policy based upon fair practices of Shariah. In addition awareness to people about Islamic products through marketing is essential in clearing their misconceptions towards investment in Islamic products.
\end{abstract}

Key Words: Islamic personal financing behavior, TRA model, Attitude, Religiosity, Subjective norms, Pricing, Regression, Moderation, Structural Equation Modeling.

\section{Introduction}

Traditionally Riba (Interest) allows the merchant to borrow money in large business deals instead of limiting his business to his own sources of wealth (Suharto, 2018). To expand the business people borrow money from usurers on interest. That might lead them to profit or devastation from their wealth. Riba has been considered a successful means for economic imperialism to invade poor countries explicitly and completely. Delays in the payment increase the debt and provide the opportunity to the lender country to invade the debtor country in the context of getting back its loan. However, the dark aspects associated with Riba system have created a need for another improved financing system which could facilitate terms and conditions between borrower and lender. Consequently reward system based upon ideology of Islam has been introduced. The reward system or Islamic banking system is now gaining popularity and is being accepted 
globally.In 1970s the idea of Islamic banking to deal with the problem of Riba had started in Pakistan. Business operations in Islamic banking follow Islamic Shariah. Shariah compliance is the most essential part of Islamic finance. Islamic financing prohibits interest based banking and promotes reward system. To earn income without taking risk is not fair (Siddiqui 2001). The desire of the banking customers to invest money according to their religious and personal values makes Islamic banking as an emerging industry in Pakistan.

The ideology of Islamic finance does not allow riba but also strictly prohibits harmful social activities Moreover it strongly encourages profit or loss sharing as well as risk-sharing transactions. Products and services in Islamic Shariah framework are offered to customers in Islamic banking and are responsible for satisfying their religious and economic needs (Ali \& Hong 2015). Among Islamic banking products the most renowned one is Islamic personal financing. Islamic personal financing is offered for providing financial assistance in meeting consumer personal needs. Social, cultural and environmental factor have a great contribution in decision making of customers towards products of Islamic financing. The studies including (Yuserrie et al,2004; Taib et al ,2008; Amin et al,2011;Rehman and Koe 2014; discussed various factors including attitude,government support, religious obligations, social influence, and pricing that influence the intention of customers to use Islamic financing products. The above studies have been conducted in Malaysia, the first Islamic country that exclusively introduced Islamic financial system focusing the banking sector. The research in the context of Islamic banking is limited in Pakistan. Mohammad et al (2015) used TRA model and investigated the effect of the above mentioned factors on intentions of customers while doing investment in Islamic financing products of Pakistan. The current study is the extension of previous studies by adding moderator in measuring the relationship between customer's intention and Islamic personal financing.

The study is using two main construct of TRA model including attitude and subjective norms along with religious beliefs with moderating role of pricing in Islamic personal financing. The primary objective of the study is to know the influence of these variables on customer's intention and the moderating role of pricing in Islamic personal financing. The current study enables to enhance the literature of Islamic finance by proposing moderating effect of pricing in customer's intention and Islamic financing. These factors are expected to be used as criteria for the selection of Islamic banks. This study is important because it will identify those factors which the consumers demand while making investment decisions regarding Islamic banking. Moreover this study is also useful for Islamic banks because awareness to the bankers about factors that consumer considers vital for investment in Islamic banks can be enhanced. The current study is also beneficial for potential researchers to acknowledge other factors that influence the intention of customers in Islamic financing.

\subsection{Review of Literature}

Islamic personal financing is based upon two principles of Sharia. These principles are qardulhasana and bay al inah. According to Khir et al (2008) Islamic banks focus on qardulhasana for designing their products. Qardulhasana is a beneficial loan given for a specific period of time without interest. The time value of money is not included in qardulhasana concept. Moreover it has excluded the concept of Riba prohibited in Islamic values. It works on good will basis and borrower only repays the principal amount. The indirect cost including office rent, employment expenditure are not included in loan, although these expenditure are associated with qardulhasana mode of financing. Amin et al (2011) argued that in practice Islamic financing is different; borrower has to pay the principal amount of loan along with the additional charges 
associated with qardulhasana. In fact the original theory of Islamic financing has not been practiced by Islamic banks.Bay-ul -inah is related to delayed transactions involving sale and purchase back of assets. Islamic banks offer a list of Islamic products on the basis of Bay-ul inah. In the mean while it facilitates the customers of Islamic banks to improve their liquidity. Most of the Islamic banks does not rely upon Bay-ul-inah to offer Islamic products because it includes hilah that favours Riba. It includes one's niyyah that has judgemental issue (Khir et al 2008).

In 1980 the focus of Islamic behavioral finance is to explain the factors that play important role in decision making of investors and customers towards Islamic banks and their products. Ahmad (2000)argues that Islamic bank cannot introduce any project contrary to Islamic values such as to finance the night club, casino and other activities that are strictly prohibited in Islam. Dusuki (2008) has conducted the study in Malaysian Islamic banks and found that participants view Islamic banks as organization that works according to Islamic values towards all of its stakeholders and should acknowledge social welfare projects. Gait and Worthington (2008) empirically compare 22 research articles to know the attitude of firms, financial institutions and individuals towards investment in Islamic banks. Their findings demonstrate that participants are not aware about the procedure to invest in Islamic financial projects.

The studies including ( Wahyuni, 2012; Abou-Youssef et al, ;2015 and Aziz et al, 2015) has identified various factors, including confidentiality, satisfaction, religiosity, attitude,influence of friendship, subjective norms cost and benefits of Islamic products, compliance of Islamic products with sharia to be used as a selection criteria for Islamic banks. Amin et al (2013) and Gumel et al (2015) and Lajuni (2017) highlight attitude, norms, religious values, awareness about Islamic products and pricing contribute in influencing the intension of customers to adopt Islamic financing. Amin et al (2013) empirically tested social norms, attitude and the Islamic financing in Malaysia. Moreover, the study has identified moderating variables pricing, religiosity and government support. The model used in the study has been developed from the theory of reasoned action (TRA) proposed by Fishbein and Ajzen (1979). The shortcoming of this paper is that the study has only tested the influence of above mentioned variables on Islamic personal financing. The moderating role of pricing, government support and religiosity is missing. The current study is basically the extension of TRA model and using its two main construct attitude and social influence along with religiosity as determinants of intension to customers for adopting Islamic personal financing. In addition the study attempts to examine the moderating role of pricing between customer's intension and Islamic personal financing. One of the robust theories that help academicians and researchers to understand the intension of customers in adopting Islamic financial products is theory of reasoned action.

\subsection{Theory of Reasoned Action and development of Hypotheses}

In 1975, theory of reasoned action has been proposed by Fishbein and Ajzen and discussed the relationship between attitude, behavior, intensions and beliefs (Taib et al. 2008). This theory has two main constructs attitude and subjective norms that influence one's behavior intention. If a person has the intention to do a behavior then he will be likely to do something. The theory of reasoned action with its main constructs along with modified variables is illustrated below.

\subsubsection{Attitude}

The theory of reasoned action (TRA) elucidates that attitude develops with positive or negative feelings for a particular behavior (Fishbein and Ajzen 1975).Amin et al, (2009) found that the influence of attitude is positive or negative on the behavior to select halal products. Amin et al (2011) and Jaffar et al. (2013) reported that attitude is considered an important determinant in 
predicting the behavior to use Islamic financing. Perception about Islamic products played a pivotal role in developing attitude. If the perception about Islamic product is positive then attitude positively influences the behavior to make investment in Islamic products (Bodibe et al 2016).Lajuna et al. (2017) argue that attitude positively affects the behavior through marketing the features of Islamic products to Muslims and non Muslims. From the above discussion first hypothesis of the study is deduced.

$\mathrm{H}_{1}=$ Attitude influences on the behavior of Islamic personal financing in Pakistan.

\subsubsection{Religiosity}

According to theory of reasoned action person consuming behavior, his choices and activities are affected by religion (Fishbein and Ajzen 1975).Souiden and Rani (2015) explain the tridimensional role of religiosity. The study shows that fear of divine punishment develop positive perception for using Islamic products of banking. Moreover, the more the person believes in Islamic frame work, the more he will invest in Islamic banking products. Alam et al (2012) also finds the role of religiosity significant in determining the intention to invest in Islamic banking services. Religiosity not only affects the cognition but also inflences the behavior of the individual. Contrary to this, Amin et al (2011) have found religiosity insignificant in assessing the intension to make investment in Islamic personal services. Bonne et al (2007) demonstrated that decision process of Muslims in purchasing Halal meat is different as compared to non- Muslims. Similarly Shaari and Afirin (2010) have discussed the role of religion in dictating the life style of religious people. The above discussion leads to generate the following hypothesis.

$\mathrm{H}_{2}=$ Religiosity influences on behavior to use Islamic personal financing in Pakistan.

\subsubsection{Subjective Norms}

Fishbein and Ajzen (1975) refer subjective norms as the action of the individual influenced by the others. Others may include society, relatives or associates. The influence of other people in the decision making of an individual to invest in Islamic products is considered as normative pressure or subjective norms. Taib et al (2008) found subjective norm also develops intention to use Islamic products of banks.Obeid \& Kaabachi (2016) discuss that the decision to adopt Islamic financing is influenced by spouse, family members and friends. An individual under social influence would show the expected behavior even though he might not be in favor of performing it. Chiu et al (2017) also considers social influence or peer pressure an important determinant in adopting Islamic financing. The following hypothesis can be developed from the above discussion $\mathrm{H}_{3}=$ Subjective Norms influences on behavior to use Islamic personal financing in Pakistan.

\subsubsection{Pricing}

Pricing refers to the most appropriate price banks select for selling the Islamic instruments. The price is the reflection of balance between customer's intention and bank's interest. Olson and Zoubi (2008) focus the first ranking factor of Islamic bank is the calculation of price of Islamic product on the basis of profit and loss, the basic ideology of Shariah in Islam. Second ranking factor is the lower monthly payments that motivate the customers to make investment in Islamic products. ( Mansour et al 2010) studied pricing is a top factor in investing Islamic products in UK .Similarly in Malaysia, the study of Amin et al (2011) explain pricing an influential factor in making investment in financial Islamic products. Chiu et al (2017) demonstrate the link between perceived financial cost and intention of customer behavior. The study is using pricing a moderating variable that develops its next hypothesis for empirical testing. 
$\mathrm{H}_{4}=$ Price moderates the relationship between customer's attitudes and behavior to use Islamic personal financing in Pakistan

$\mathrm{H}_{5}=$ Price moderates the relationship between customer's religious beliefs and behavior to use Islamic personal financing in Pakistan

$\mathrm{H}_{6=}$ Price moderates the relationship between customer's subjective norms and behavior to use Islamic personal financing

\subsection{Conceptual Frame work}

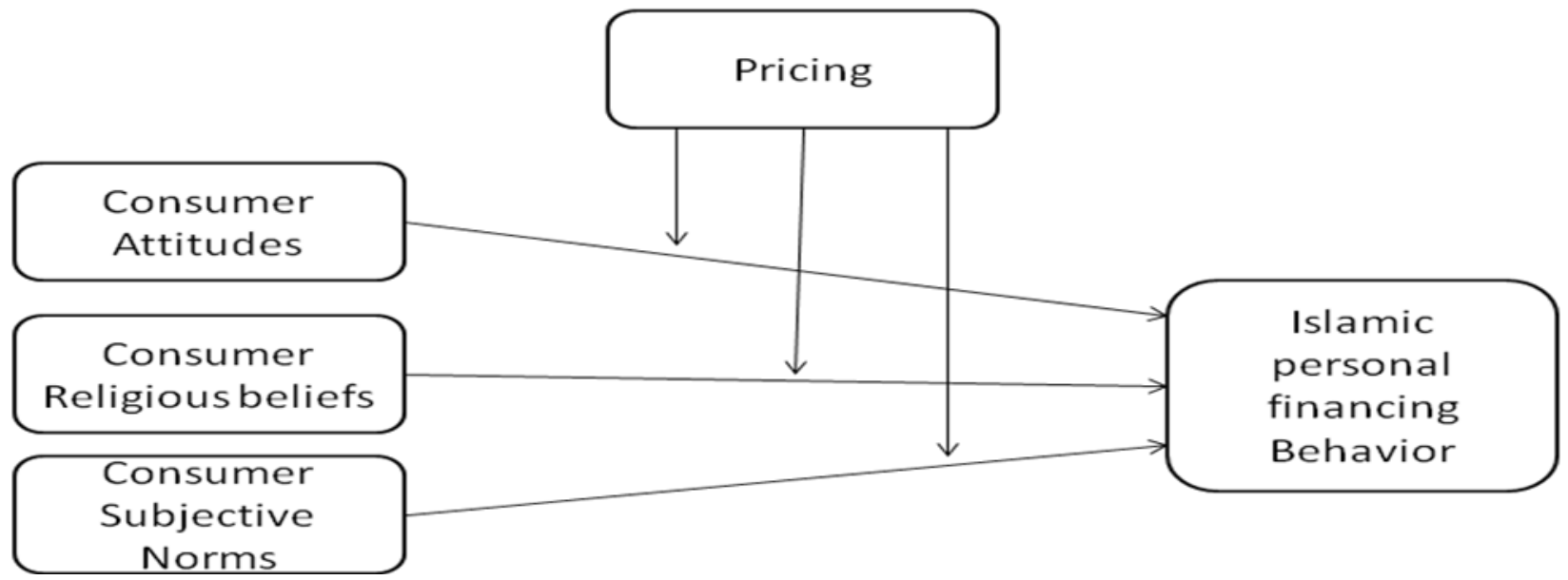

Figure 1 Conceptual frame work

\subsection{Econometric model}

On the basis of this conceptual framework the regression model of the current study is as follows

$\mathrm{IIPF}=\beta_{\mathrm{o}}+\beta_{1} \mathrm{AT}+\beta_{2} \mathrm{RS}+\beta_{3} \mathrm{SN}+\beta_{4} \mathrm{P}+€$

$\mathrm{IIPF}=\beta_{0}+\beta_{1} \mathrm{AT}+\beta_{2} \mathrm{P}+\beta_{3}(\mathrm{AT} \times \mathrm{P})+€$

$\mathrm{IIPF}=\beta 0+\beta 1 \mathrm{RS}+\beta_{2} \mathrm{P}+\beta_{3}(\mathrm{RS} \times \mathrm{P})+€$

$\mathrm{IIPF}=\beta 0+\beta_{1} \mathrm{SN}+\beta_{2} \mathrm{P}+\beta_{3}(\mathrm{SN} \times \mathrm{P})+€$

Where as

$\mathrm{IIPF}=$ Intention to use Islamic personal financing

AT $=$ Attitude

$\mathrm{RS}=$ Religiosity

$\mathrm{SN}=$ Subjective norms

$\mathrm{P}=$ Price

\subsection{Study Methodology}

In this study, data is collected from Islamic bank customersin a contrived study setting that uses natural environment to obtain true information from customers. The data is taken from individual consumers of Islamic banks in the current study. The data is cross-sectional and gathered from customers of twin cities of pure Islamic banks from Rawalpindi \& Islamabad using convenient sampling technique. The total of 300 questionnaires was distributed and received 250 
questionnaires back. Out of which 30 responses were excluded due to missing information. Finally in this study 220 questionnaires were used for analysis.

\subsection{Instruments and Sample Characteristics}

In this study the primary data was collected using the questionnaires adapted from earlier studies. The instruments of Consumer attitude, Social norms, Religiosity, Price and Intention to use Islamic personal financing were adapted using 5 point likert scale (Lada et al., 2009; Amin et al., 2011; Abdullah et al., 2012). Male respondents in the study were 115 (52.3 percent) and female was 105 (47.7 percent). Moreover, in the survey married respondents were 66 (29.5 percent) and unmarried were 155 (70.5 percent). In the survey respondents of different academic level participated, bachelors 40.5 percent, master level 39.1 percent, intermediate level 10.2 percent, metric level 8.2 percent and $\mathrm{PhD}$ level 2.3 percent. Different age groups of respondents have been observed in the study, 15 percent (30-35 age group), 3.6 percent ( 35-40 age group), 3.6 percent ( 40-45 age group) and 9 percent ( above 45 age group). In addition respondents of different sectors participated 49.5 percent (private sector), 33.2 percent (self-employed) and 17.3 percent (government sector).

\section{Data Analysis and Results}

Hypothesized model of the study is tested in three phases in this section. First phase is comprised of descriptive statistics, reliability, validity and the measurement model, unidimensionality and common method bias regarding all the constructs. In the second phase structural validation of direct effects of the model suggested by Byrne (2001) is presented. The three steps of SEM can also be summed up into two stages, measurement model and structural model. In the third phase, the moderation hypotheses are tested using two way interaction terms by Hensler and Chin (2010). The descriptive and statistical analysis regarding the variables are tested using SEM technique through using SPSS 20 and AMOS 21 software's.

\subsection{Descriptive Analysis}

The descriptive analysis reflected the mean values ranging from 3.5 to 2.9 and the standard deviations exists from .51 to .58 .As the values of skewness and kurtosis are in acceptable range $(-3$ to +3$)$ depicting the data is normal (Ghasemi\& Zahediasl, 2012). Moreover, the correlation among all the constructs correlation exists below 0.9 that shows no issue of multicollinearity prevails in this study (Tabachnick \& Fidell, 2001). Furthermore, variance inflation and tolerance are also checked for testing multicollinearity. Table 4.1 shows that multicollinearity does not prevail in the data as all VIF values are <10 and tolerance values are > .1 (Hair et al., 2009). 


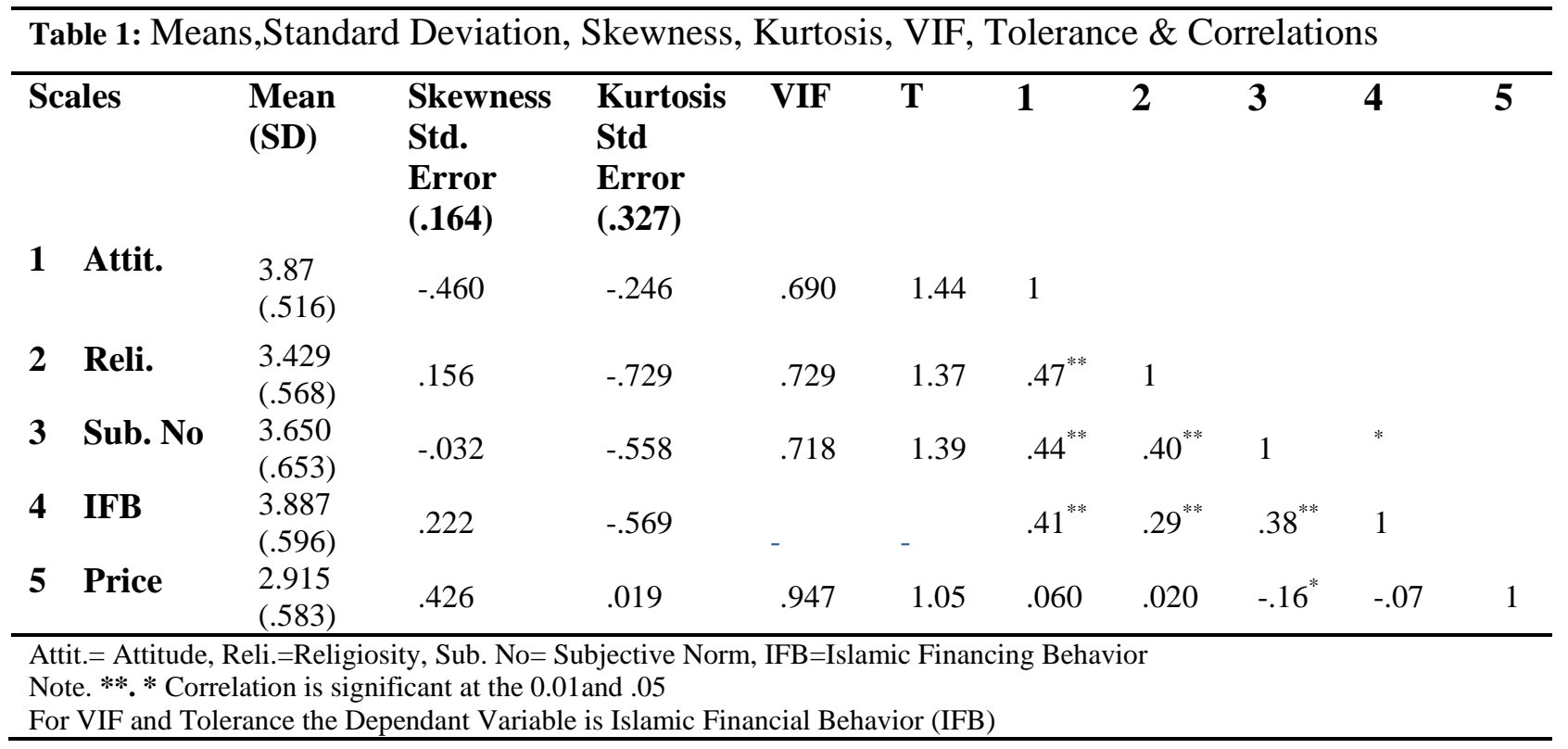

For convergent validity the CFA is conducted. The convergent validity is assessed in table 2 that shows all constructs items factor loading retained for this study has their factor loading (St.FL) >.50 (Hu \& Bentler, 1999). The results also show that in table II indicated that all constructs internal consistency(IC) which is Cronbach alpha and construct reliability (CR) which is the composite reliability are $\geq .70$ (Hair, Black, Babin, Anderson, \& Tatham, 2006). Thus internal consistency and reliability of constructs has been proved. Furthermore, Comparative Fit Index (CFI) and Square multiple correlations (SMC) are used to assess the unidimensionality. CFI that explains the good fit regarding data should be $>0.80$ (Hu \& Bentler, 1999). All values of CFI are above .80 show good fit of data. Finally, the square multiple correlations are also calculated in order to ensure the reliability of the items and detecting issues generating the observed errors. According to $\mathrm{Hu}$ and Bentler (1999) if the FL values are (below) $<0.50$ and SMC values are (less than) $<0.20$ of any item than those items are required to be omitted from further processing. Table II shows that all values of SMC >.20 and St. FL. >.50 are only retained in order to reduce the problematic error from the data.

Table 2: Convergent Validity, Reliability and Unidimensionality

$\begin{array}{llllllll} & & \text { Square } & & & & \\ \text { Multiple } & \text { CFI } & \text { Standardized } & & \\ \text { Variables } & \text { Correlations } & & \text { Factor } & \text { IC } & \text { CR } \\ & \text { Items } & \text { Loadings } & & & \\ & & & \text { (St. FL) } & & & \end{array}$




\begin{tabular}{|c|c|c|c|c|c|c|c|}
\hline \multirow{4}{*}{1 . } & & Atti 1 & .30 & & .55 & & \\
\hline & Investor's & Atti 4 & .51 & \multirow{3}{*}{.991} & .72 & \multirow[t]{3}{*}{.78} & \multirow{3}{*}{.78} \\
\hline & Attitude & Atti 5 & .50 & & .71 & & \\
\hline & & Atti 6 & .60 & & .78 & & \\
\hline \multirow[t]{3}{*}{2.} & Investor's & Relob 3 & .78 & \multirow{3}{*}{1.00} & .88 & \multirow{3}{*}{.78} & \multirow{3}{*}{.79} \\
\hline & Religious & Relob 4 & .32 & & .57 & & \\
\hline & Beliefs & Relob 5 & .60 & & .78 & & \\
\hline \multirow{5}{*}{3.} & & SubNorm1 & .39 & \multirow{5}{*}{.957} & .63 & \multirow{5}{*}{.84} & \multirow{5}{*}{.75} \\
\hline & Investor's & SubNorm2 & .67 & & .82 & & \\
\hline & Subjective & SubNorm3 & .32 & & .56 & & \\
\hline & \multirow[t]{2}{*}{ Norms } & SubNorm4 & .28 & & .53 & & \\
\hline & & SubNorm5 & .25 & & .50 & & \\
\hline \multirow[t]{5}{*}{4.} & Islamic & Intention1 & .52 & \multirow{3}{*}{1.00} & .72 & \multirow{3}{*}{.70} & \multirow{3}{*}{.70} \\
\hline & Financial & Intention2 & .48 & & .70 & & \\
\hline & Behavior & Intention5 & .30 & & .55 & & \\
\hline & & Pricing1 & .28 & \multirow{6}{*}{.90} & .54 & \multirow{6}{*}{.82} & \multirow{6}{*}{.82} \\
\hline & & Pricing2 & .46 & & .68 & & \\
\hline \multirow[t]{4}{*}{5.} & Pricing & Pricing3 & .53 & & .73 & & \\
\hline & & Pricing4 & .35 & & .59 & & \\
\hline & & Pricing5 & .61 & & .78 & & \\
\hline & & Pricing6 & .46 & & .68 & & \\
\hline
\end{tabular}

Finally using the Uni dimensionality concept all the variables in the direct path relationships co variation are assessed for testing the overall measurement model appropriateness. The Figure 1 comprised of independent and dependant constructs.

There are three categories of fit indices that are absolute; Incremental and parsimony indices are used in this study. First for absolute fit indices the value of Chi-square / $d f<$ 5 , RMSEA $<.08$ are checked. For Incremental fit indices the values of CFI $>.80$, are reported and for Parsimonious fit the value of AGFI >.80 is checked with their acceptable ranges (Hu \& Bentler, 1999). 


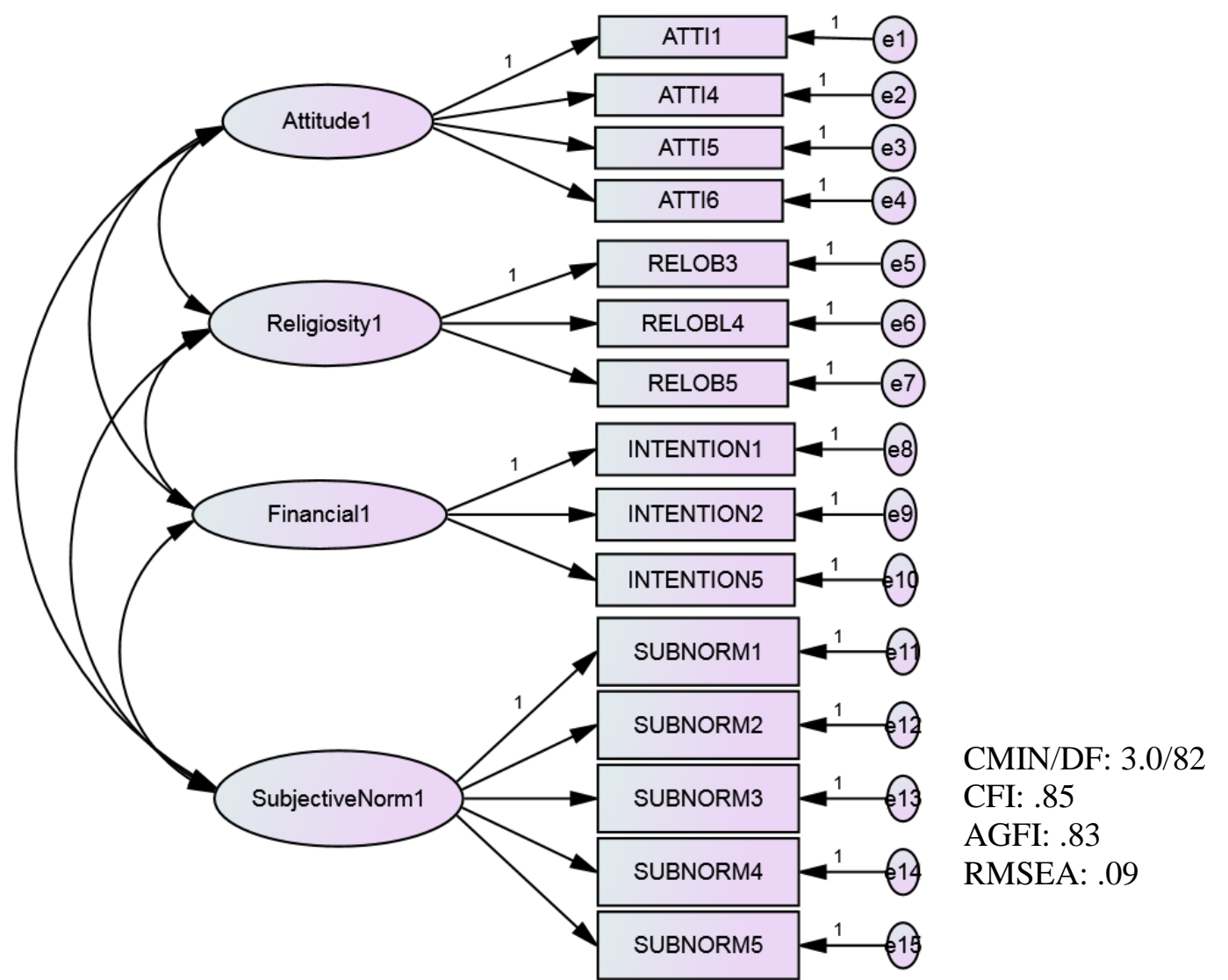

Figure 1: $*^{* *} p<.001$, CMIN/DF: Chi- Square / Degree of Freedom, AGFI: Adjusted Goodness of Fit index, RMSEA: Root Mean Square Error of Approximation

\subsection{Common method bias}

Scholars put their arguments about the existence of common method bias (CMB) in the self reporting data (Conway \& Lance, 2010). This study has used Harman's one-factor test for identifying the existence of CMB (Bish, Newton \& Johnstan, 2015). The EFA of all the items disclosed 27 factors having the first factor accounting only $18.64 \%$ of the total variance which is $<50 \%$ regarding the cutoff point that shows that CMV is not the issue in this study. 


\begin{tabular}{|c|c|c|c|c|c|c|}
\hline \multirow[t]{2}{*}{ Component } & \multicolumn{3}{|c|}{ Initial Eigen values } & \multicolumn{3}{|c|}{ Extraction Sums of Squared Loadings } \\
\hline & Total & $\begin{array}{l}\% \\
\text { Variance }\end{array}$ & $\begin{array}{l}\text { of Cumulative } \\
\%\end{array}$ & Total & $\begin{array}{l}\% \\
\text { Variance }\end{array}$ & $\begin{array}{l}\text { of Cumulative } \\
\%\end{array}$ \\
\hline 1 & 5.035 & 18.649 & 18.649 & 5.035 & 18.649 & 18.649 \\
\hline 2 & 3.941 & 14.598 & 33.247 & & & \\
\hline - & . & $\cdot$ & - & & & \\
\hline · & $\cdot$ & · & • & & & \\
\hline 0 & 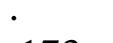 & (s) & & & & \\
\hline 25 & .173 & .640 & 98.872 & & & \\
\hline 26 & .156 & .579 & 99.451 & & & \\
\hline 27 & .148 & .549 & 100.000 & & & \\
\hline
\end{tabular}

\subsection{Hypothesis Testing}

For structural model the examination of standardized regression estimates are tested for checking the relationship of cause and effect between the variables. The variables relationships are found strong in the study that ensure fitness of the model (Blunch, 2012).While testing the direct path coefficient of model, Attitude with path coefficient .44 and $\mathrm{P}$ value $<.001$ and religiosityhaving path coefficient .26 and $\mathrm{P}$ value $<.05$ are positively related to Islamic Personal financing behavior. In contrast, surprisingly the subjective norm having path coefficient as -.18 and $\mathrm{P}$ value $<.01$ are also significant. Hence proving $\mathrm{H} 1, \mathrm{H} 2$ and $\mathrm{H} 3$ supported.

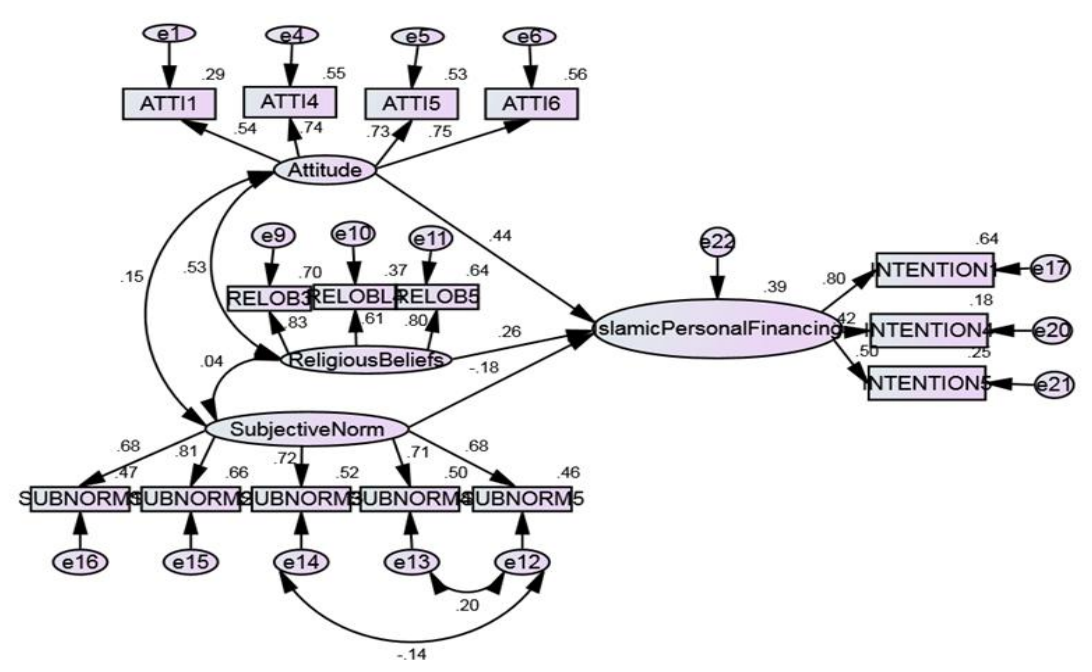

Figure 2: Hypothesis Testing $* * * p<.001$, 


\subsection{Testing of Moderating Effects}

In the third phase the hypothesis $\mathrm{H} 4, \mathrm{H} 5$ and $\mathrm{H} 6$ are tested to identify the moderation through interaction effects of pricing upon the relationship between Attitude, Religiosity, Subjective Norm and Islamic Personal financing using partial least square path modeling (Hensler \& Chin, 2010). At first the moderation effect of pricing is tested by interaction term between Investor Attitude and. the Islamic Personal financing behavior. The result is found to be insignificant with the P-value $>.05$ so $\mathrm{H} 4$ of the study is rejected.

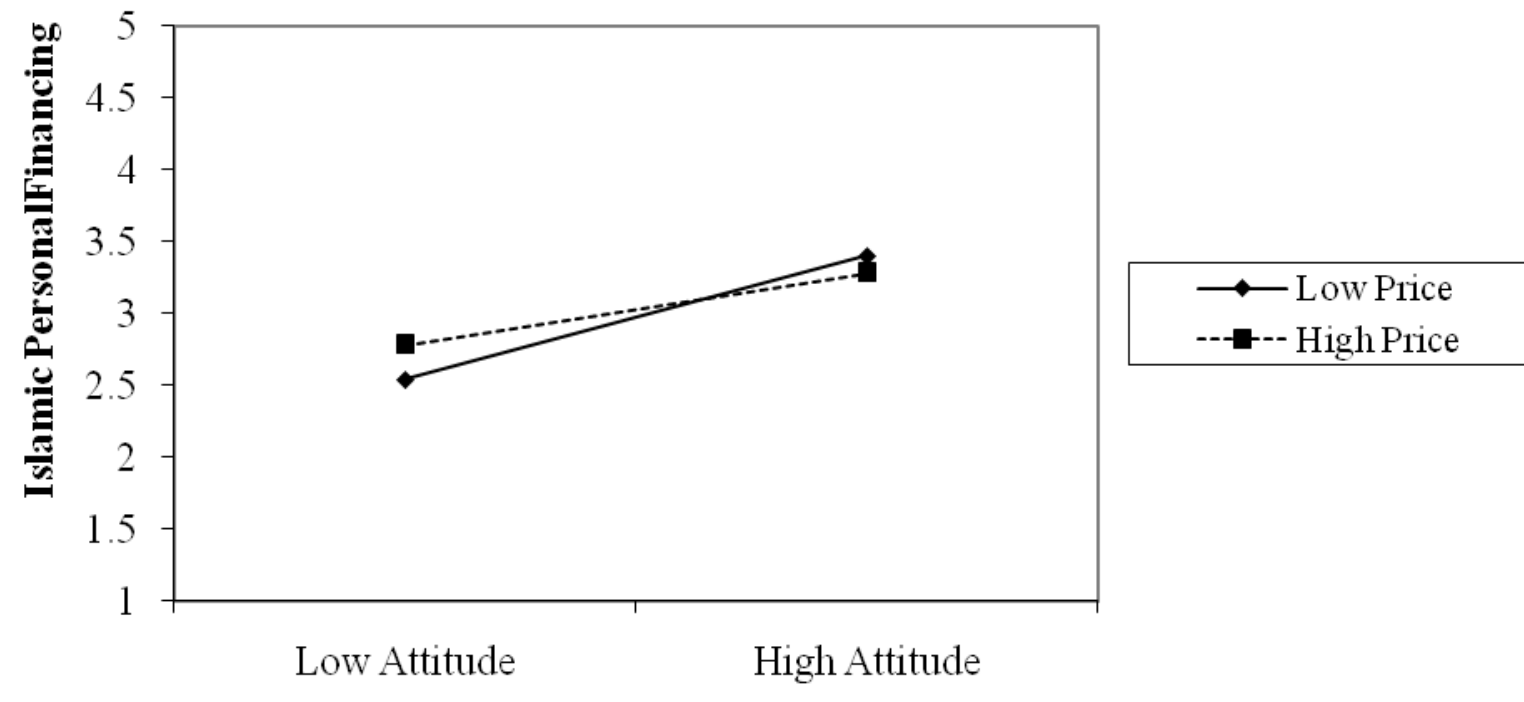

Figure 2 Moderation result of $\mathrm{H} 4$

Secondly, the moderation effect of pricing is tested by interaction term between Investor Religiosity and the Islamic Personal financing behavior. The result is found to be significant with the P-value $<.001$ so H5 is accepted. 

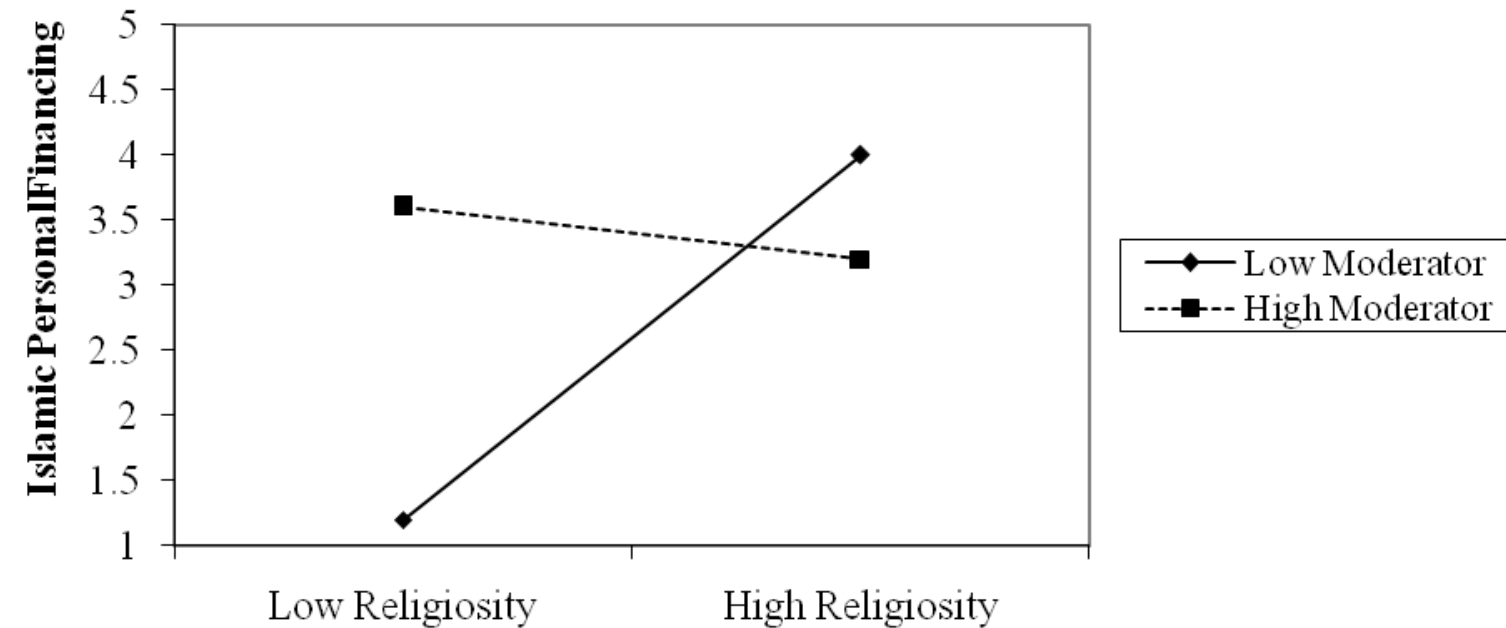

Low Religiosity

High Religiosity

\section{Figure 3 Moderation result of $\mathbf{H 5}$}

Lastly, in the sixth hypothesis the moderation effect of pricing is tested by interaction term between Subjective norms and the Islamic Personal financing behavior. The result is found to be insignificant with the P-value $>.05$ so H6 is rejected.
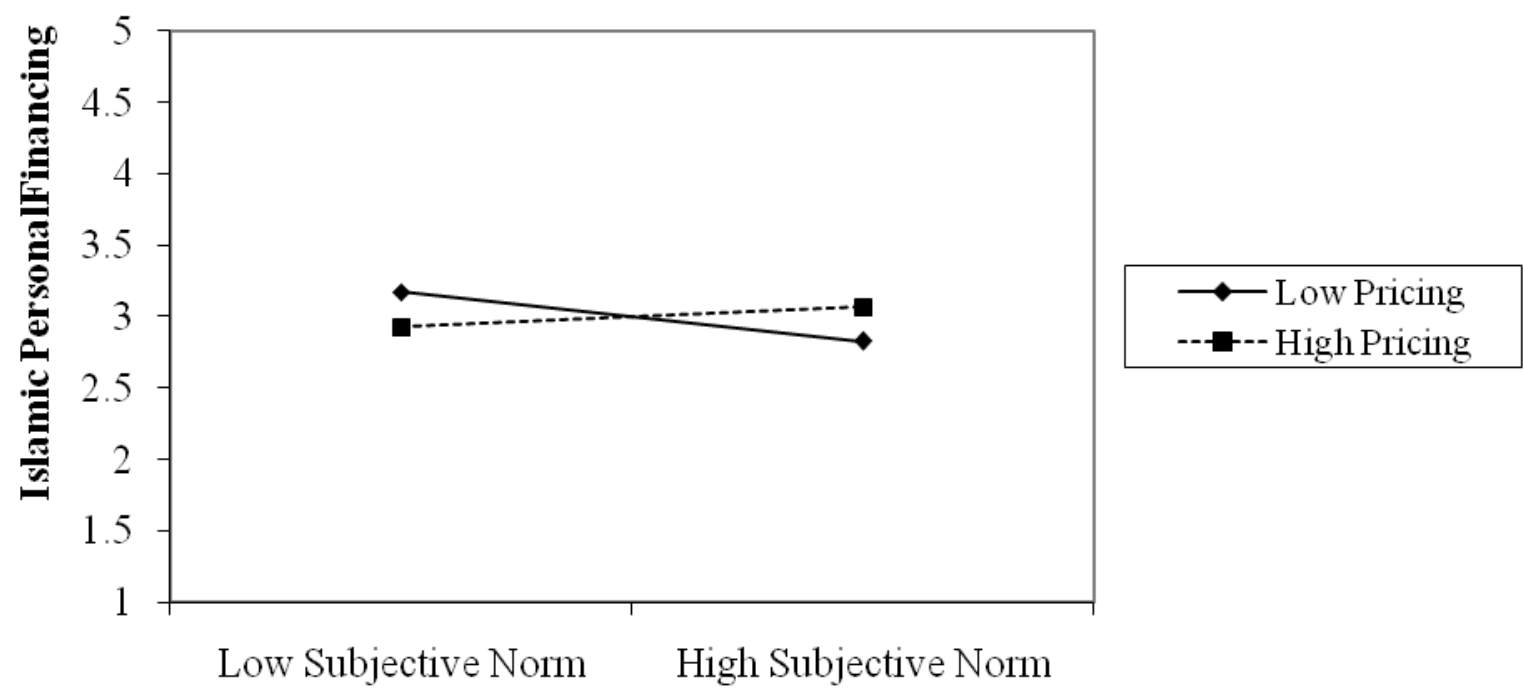

Figure 4 Moderation result of $\mathrm{H6}$ 


\subsection{Discussion}

The findings of current study supports that the conventional theory of TRA is appropriate in the context of Islamic banking of Pakistan. The significant coefficients of attitude, social norms and religiosity at significant level reveal that these factors determine the intention of customers to adopt Islamic personal financing. Attitude and Religious values positively influence the Islamic personal financing. The results of the current study are consistent with Bodibe et al (2016),Souiden and Rani (2015) and Alam et al (2012)and demonstrates that Islamic values, divine of punishment, prohibition of interest and positive perception about halal products play a pivotal role in selecting Islamic personal financing for investment. In contrast, the social norms constructs negatively influence on intention to use Islamic personal financing and contradicts with the previous studies of Amin et al (2011) and Ali et al (2015). The reason for negative influence may be the wrong perception about Islamic banks in Pakistan.It is a common observation that people culturally perceive interest and reward in a similar context. Not only that they also view that the financial institutions (either Islamic or non Islamic) are dealing interest or profit in the similar way. In addition, Ahmed et al (2014) conducted the study to test the relationship between pricing of Islamic bank products and conventional bank products and found that there is no major difference between lending rates of Islamic and conventional banks. This study provides the empirical evidence of consumer misconceptions that the Islamic deposits are not interest free.

The current study also covers the gap explained by Amin et al (2011) and tested pricing as a moderator between intention and Islamic personal financing. Interaction terms illustrate that pricing moderates the relationship between intention and Islamic personal financing in the perspective of religiosity. Latip et al (2017) also support that the muslims are religiously obliged to make investment or purchase those products that lie under the frame work of Shariah. Shariah used the term halal for those Islamic products that are designed on the basis of teachings of Islam. Religious people trust that pricing of Islamic products are fair because they are not fixed as interest and determined on the basis of risk sharing. So religious people feels that the Islamic products are reliable and don't harm their religious beliefs and practices. Thus religious people will have their intention to adopt Islamic personal pricing because price is transparent.However in contrast, pricing doesn't significantly moderate the relationship between other two constructs of intention such as attitude and social norms and Islamic personal financing behavior. The possible reason is that religious people do not consider materialistic and social perspectives in decision making. Therefore pricing does not moderate in the context of attitude and social norms.

\subsection{Conclusion}

The modified TRA model with moderating role of pricing has been empirically examined in Islamic banks of Pakistan. Attitude, social norms and religiosity influence the intention of customers in adopting Islamic personal financing. 
This study has focused only in dual cities of Pakistan. The future study may be conducted in Islamic banks throughout Pakistan. In future the comparative analysis of all Islamic banks globally in the context of TRA model can be analyzed. More factors such as reward, risk and trust can be analyzed in future as the predictors that influences the intention of customers in Islamic personal financing. Regression results of the study show that two main constructs of TRA model including attitude and social norms influences the behavior of consumers in adopting Islamic personal financing. Moreover religiosity, the added variable in TRA has also a significant influence on consumer's intention in Islamic personal products. The results of the study support that TRA model is practically implementing in Pakistan in the context of Islamic banking. Furthermore, the moderation results infer that price significantly moderates the relationship between intentions of customers in purchasing Islamic banking products with regard to religiosity. Islamic bankers should adopt pricing policy based upon fair practices of Shariah. In addition awareness to people about Islamic products through marketing is essential in clearing their misconceptions towards investment in Islamic products.

\section{References}

Abd. Aziz, H., Echchabi, A., Houssem Eddine, C.O., Ayedh, A.M., Musse, O.S.H. \& Azouzi, D.(2015). Current state and future prospects of Islamic banking in Morocco: An empirical investigation. Journal of Emerging Economies \& IslamicResearch, 3 (2), 1-10

Abou-Youssef, M.M.H., Kortam, W., Abou-Aish, E. \& El-Bassiouny, N.(2015). Effects of religiosity on consumer attitudes toward Islamic banking in Egypt. International Journal of Bank Marketing, 33(6) 786-807

Ahmad, K. (2000). Islamic finance and banking: the challenge and prospects. Review of Islamic Economics, Vol. 9, pp. 57-82

Ahmed, S., Rahman, A., Ahmed, S., \& Ullah, G. M. (2014). Pricing linkage between Islamic banking and conventional banking: The case of Bangladesh

Alam, S.S., Janor, H., Zanariah, C.A.C., \& Ahsan, M.N. (2012), Is religiosity an important factor in influencing the intention to undertake Islamic home financing in Klang Valley? World Applied Sciences Journal, 19(7), 1030-1041

Ali, M., \& Chin-Hong, P. (2015). Factors affecting intention to use Islamic personal financing in Pakistan: Evidence from the modified TRA model

Amin, H., Abdul-Rahman, A.-R., \& Abdul-Razak, D. (2013). An integrative approach for understanding Islamic home financing adoption in Malaysia, International Journal of Bank Marketing, 31(7) 544-573

Amin, H., Rahim Abdul Rahman, A., Laison Sondoh Jr, S., \& Magdalene Chooi Hwa, A. (2011). Determinants of customers' intention to use Islamic personal financing: The case of Malaysian Islamic banks. Journal of Islamic Accounting and Business Research, 2(1), 22-42

Bish, A., Newton, C., \& Johnston, K. (2015). Leader vision and diffusion of HR policy during change. Journal of Organizational Change Management, 28(4), 529-545

Blunch, N. (2012). Introduction to structural equation modeling using IBM SPSS statistics and AMOS. Sage 
Bodibe, S., Chiliya, N., \& Chikandiwa, C. T. (2016). The factors affecting customers'Bonne, K., Vermeir, I., Bergeaud-Blackler, F., \& Verbeke, W. (2007). Determinants of halal meat consumption in France. British Food Journal, 109(5), 367-386

Bonne, K., Vermeir, I., Bergeaud-Blackler, F., \& Verbeke, W. (2007). Determinants of halal meat consumption in France. British Food Journal, 109(5), 367-386

Byrne, B. M. (2001). Structural equation modeling with AMOS, EQS, and LISREL: Comparative approaches to testing for the factorial validity of a measuring instrument. International journal of testing, 1(1), 55-86

Chiu, J. L., Bool, N. C., \& Chiu, C. L. (2017). Challenges and factors influencing initial trust and behavioral intention to use mobile banking services in the Philippines. Asia Pacific Journal of Innovation and Entrepreneurship, 11(2), 246-278

Conway, J. M., \& Lance, C. E. (2010). What reviewers should expect from authors regarding common method bias in organizational research. Journal of Business and Psychology, 25(3), 325-334.

Dusuki, A. W. (2008). Understanding the objectives of Islamic banking: a survey of stakeholders' perspectives. International Journal of Islamic and Middle Eastern Finance and Management, $1(2), 132$

Dusuki, A., \& Abdullah, N. (2007). Why do Malaysian Customers Patronize Islamic Banks? International Journal of Bank Marketing, 25(3)142-160.Financial Issues, 7(1)

Fishbein, M. (1979). A theory of reasoned action: some applications and implications

Fishbein, M., \& Ajzen, I. (1975). Belief, attitude, intention and behavior: An introduction to theory and research

Gait, A., \& Worthington, A. (2008). An empirical survey of individual consumer, business firm and financial institution attitudes towards Islamic methods of finance. International Journal of Social Economics, 35(11), 783-808

Ghasemi, A., \& Zahediasl, S. (2012). Normality tests for statistical analysis: a guide for nonstatisticians. International journal of endocrinology and metabolism, 10(2), 486

Gumel, A.M., Othman, M.A. \& Yusof, R.M. (2015). Critical Insights into an Integrated Literature Review on Customers'Adoption of Islamic Banking Research. International Journal of Scientific Research and Innovative Technology, 2 (6)45-57

Hair, J., Anderson, R., Tatham, R., \& Black, W. (2007). Multivariate data analysis 7th edition prentice hall. New Jersey

Hair, J., Black, W., Babin, B., Anderson, R. \& Tatham, R. (2006) Multivariate Data Analysis. 6th Edition, Pearson Prentice Hall, Upper Saddle River

Henseler, J., \& Chin, W. W. (2010). A comparison of approaches for the analysis of interaction effects between latent variables using partial least squares path modeling. Structural Equation Modeling, 17(1), 82-109

Hu, L. T., \& Bentler, P. M. (1999). Cutoff criteria for fit indexes in covariance structure analysis: Conventional criteria versus new alternatives. Structural equation modeling: $a$ multidisciplinary journal, 6(1), 1-55

Hu, L. T., \& Bentler, P. M. (1999). Cutoff criteria for fit indexes in covariance structure analysis: Conventional criteria versus new alternatives. Structural equation modeling: a multidisciplinary journal, 6(1), 1-55 
Jaffar, M. A., \& Musa, R. (2013). Determinants of attitude towards Islamic financing among Halal-certified micro and SMEs: A proposed conceptual framework. International Journal of Education and Research, 1(8), 1-10

Khir, K., Gupta, L. \& Shanmugam, B. (2008), Islamic Banking: A Practical Perspective,Pearson Longman, Petaling Jaya

Koe, W. L., \& Rahman, N. Z. A. (2014). The Use of Ar-Rahnu by Islamic Bank Customers in Malaysia. In Proceedings of the International Conference on Science, Technology and Social Sciences (ICSTSS) 2012 (pp. 11-18). Springer, Singapore

Lajuni, N., Wong, W. P. M., Yacob, Y., Ting, H., \& Jausin, A. (2017). Intention to use Islamic banking products and its determinants. International Journal of Economics and Financial Issues, 7(1), 329-333

Latip, M., Yahya, M. H., \& Junaina, M. (2017). Factors Influencing Customer's Acceptance of Islamic Banking Products and Services. IKONOMIKA, 2(1), 1-18

Mansour, W., Ben Abdelhamid, M., Masood, O., \& Niazi, G. S. K. (2010). Islamic banking and customers' preferences: the case of the UK. Qualitative Research in Financial Markets, 2(3), 185-199

Md-Taib, F.M., Ramayah, T. \& Abdul-Razak, D. (2008), "Factor influencing intention to use diminishing partnership home financing", International Journal of Islamic and Middle Eastern Finance and Management, Vol. 1 No. 3, pp. 235-248.

Obeid, H., \& Kaabachi, S. (2016). Empirical investigation into customer adoption of Islamic banking services in Tunisia. Journal of Applied Business Research, 32(4), 1243

Olson, D., \& Zoubi, T. A. (2008). Using accounting ratios to distinguish between Islamic and conventional banks in the GCC region. The International Journal of Accounting, 43(1), 4565 .

Shaari, J. A. N., \& Mohd Arifin, N. S. (2009). Dimension of halal purchase intention: A preliminary study.

Siddiqui, S. H. (2001). Islamic banking: true modes of financing. New Horizon, 109(2), 15-20.

Souiden, N., \& Rani, M. (2015). Consumer attitudes and purchase intentions toward Islamic banks: the influence of religiosity. International Journal of Bank Marketing, 33(2), 143-161.

Souiden, N., \& Rani, M. (2015), Consumer attitudes and purchase intentions toward Islamic banks: The influence of religiosity. International Journal of Bank Marketing, 33(2), 143-161.

Suharto, U. (2018). Riba and interest in Islamic finance: semantic and terminological issue. International Journal of Islamic and Middle Eastern Finance and Management, 11(1), 131138.

Tabachnick, B.G. and Fidell, L.S. (2001) Using Multivariate Statistics. 4th Edition, Allyn and Bacon, Boston

Wahyuni, S. (2012). Moslem Community Behavior in the Conduct of Islamic Bank: The Moderation Role of Knowledge and Pricing. Procedia - Social and Behavioral Sciences, 57(9) 290-298.

Wahyuni, S. (2012). Moslem community behavior in the conduct of Islamic bank: The moderation role of knowledge and pricing. Procedia-Social and Behavioral Sciences, 57, 290-298. 